\title{
Perfusion Culture
}

National Cancer Institute

\section{Source}

National Cancer Institute. Perfusion Culture. NCI Thesaurus. Code C112955.

A type of culture in which cells are grown and are continuously fed new culture media. 